\title{
THE OCCURRENCE OF NATIVE ANTISHEEP AMBOCEPTOR IN HUMAN SERUM AND ITS IMPORTANCE IN THE PERFORMANCE OF THE WASSERMANN REACTION *
}

\author{
RICHARD DEXTER, M.D., AND C. L. CUMMER, M.D. \\ CLEVELAND
}

That there occurs in certain human serums a substance which hemolyzes sheep corpuscles in the presence of complement has been known for a considerable time. It has been our purpose to find out how much the presence of this substance in serums which reacted positively to the Wassermann test could affect the final result of the reaction.

In 1908 Bauer $^{1}$ pointed out that use might be made of this substance - to which we shall refer as native antisheep amboceptor - in the complement fixation test for syphilis, and he suggested substituting this native amboceptor for the rabbit sheep amboceptor used in the Wassermann reaction. The Wassermann technic would be simplified in this way, as one of the reagents would be eliminated without endangering its accuracy. This procedure is known as the Bauer modification of the Wassermann reaction. Shortly after this, Bering ${ }^{2}$ reported a series of 123 cases, in which both the Wassermann reaction and the Bauer modification were used. He found that the results of the two reactions checked in all of the 123 cases, but other observers who compared the two methods found that the presence of this native antisheep amboceptor was too inconstant to be depended on. Hoehne found that at least 10 per cent. of the adults had in their serum either none of this substance or an insufficient amount for the reaction. Meirowsky ${ }^{4}$ found Bauer's modification to be inaccurate and unreliable as compared with the Wassermann reaction. Swift ${ }^{5}$ compared the results of the Bauer reaction with the Wassermann and Noguchi reactions in sixty-five serums. He found sufficient native amboceptor to carry out the Bauer modification in 38 per cent. of the cases, and an insufficient amount in 60 per cent. of the cases. Noguchi ${ }^{6}$ found that this native antisheep amboceptor varied much in different

\footnotetext{
${ }^{*}$ From the H. K. Cushing Laboratory of Experimental Medicine, Western Reserve University, Cleveland. Received for publication Feb. 5.

1. Bauer, J.: Deutsch. med. Wchnschr., 1908, xxxiv, 698; Berl. klin. Wehnschr., 1908, xlv, 834.

2. Bering, F.: München. med. Wehnsehr., 1908, xlviii, 2476.

3. Hoehne, F.: Berlin. klin. Wchnschr., 1910, xlvii, 334.

4. Meirowsky, E.: Berl, klin. Wehnschr., 1909, xlvi, 152.

5. Swift, H. F.: The Archives Int. Med., 1909, iv, 376.

6. Noguchi, H.: Jour. Exper. Med., 1909, ix, 392.
} 
serums; in some instances the amboceptor content was as high as 20 units. Kaliski ${ }^{7}$ found from slight to large amounts in about 53 per cent. of human adults. The above observations go to show that while there is in certain human serums enough antisheep amboceptor to hemolyze the amount of sheep cells used in the Wassermann reaction, this is by no means a constant characteristic.

Morgenroth and Sachs, ${ }^{8}$ Noguchi $^{9}$ and others have shown that with a constant amount of red cells, hemolysis will occur when the amounts of amboceptor and complement are varied inversely to each other. In other words, hemolysis will occur with a constant amount of sheep corpuscles even if less than one unit of complement be used when the amount of amboceptor is increased proportionately. It is therefore conceivable that in a serum which contains enough native amboceptor for the purposes of a complement fixation test, the addition of the usual dose of artificial amboceptor might well change a positive reaction into a negative one by causing hemolysis to take place where none should occur.

In order to obtain an idea of the amount of native antisheep amboceptor in human serums which were to be tested by the Wassermann reaction, Swift suggested the addition of a new control tube to the Wassermann system. This tube would contain one-half the amount of human serum used in the test, with the usual amount of complement and sheep-cell emulsion. He thought that if hemolysis occurred in this control tube "it would give a clue to the cause of negative findings with certain serums and would justify repeating the reaction with the Bauer modification."

Acting on this suggestion we have controlled a large number of Wassermann reactions with this extra test. We have used the modified Wassermann system recommended by Swift, ${ }^{\mathbf{5}}$ in which one-half the amount of serum and reagents employed in Wassermann's original technic are used. The tube containing only the patient's serum, complement and cell emulsion, which we may call the Bauer control tube, is incubated for one hour, during which time the reactions undergo their first incubation. If at the end of the hour the Bauer control shows complete hemolysis, it has been our custom to perform the test without the addition of the artificial amboceptor, depending on the native amboceptor to carry out the reaction.

We have controlled 1,686 reactions in the above manner and have found sufficient native amboceptor in 301 serums (17.9 per cent.), while in 1,385 (82.1 per cent.) there was either none or an insufficient amount.

We have also reviewed our notes on ninety-five additional cases in which two or more Wassermann reactions had been done. In sixty-two

7. Kaliski, D. J.: The Archives Int. Med., 1910, vi, 205.

8. Morgenroth, J., and Sachs, H.: Berl. klin. Wchnschr., 1902, xxxix, 817.

9. Noguchi, H.: The Serum Diagnosis of Syphilis, J. B. Lippincott Co., 1910. 
of these cases there was no native antisheep amboceptor at any time. Five showed a sufficient amount of native amboceptor constantly on two or more observations, while twenty-eight cases showed an insufficient amount of native amboceptor on one occasion and a sufficient amount on others, or vice versa. These observations were made over periods of time varying from weeks to months, and merely suggest that the native antisheep amboceptor in human serum is a distinctly inconstant body even in one and the same individual.

\section{Table of Positive Reactions Changed by the addition of artificial}

\begin{tabular}{|c|c|c|c|c|c|}
\hline \multicolumn{6}{|c|}{ АMBOCEPTOR* } \\
\hline $\begin{array}{l}\text { No. } \\
\ldots\end{array}$ & $\begin{array}{l}\text { Without } \\
\text { Artificial }\end{array}$ & $\begin{array}{l}\text { With } \\
\text { Artificial }\end{array}$ & $\begin{array}{l}\text { No. } \\
\ldots\end{array}$ & $\begin{array}{l}\text { Without } \\
\text { Artificial }\end{array}$ & $\begin{array}{l}\text { With } \\
\text { Artificial }\end{array}$ \\
\hline$\ldots$ & Amboceptor & Amboceptor & & Amboceptor & Amboceptor \\
\hline $\begin{array}{l}1 \\
2\end{array}$ & .. +++ & ++ & 15 & $\cdots++$ & - \\
\hline 3 & & +1 & 17 & & + \\
\hline 4 & & $+t$ & 18 & ++ & + \\
\hline 5 & & ++ & 19 & $+t$ & \pm \\
\hline 6 & 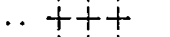 & $+\dot{t}$ & 20 & . $+\dot{+}$ & \pm \\
\hline 7 & & $+t$ & 21 &.$+t$ & 一 \\
\hline $\begin{array}{l}8 \\
9\end{array}$ & + & + & 22 & . $+t$ & - \\
\hline 10 & $1+$ & + & 23 & + & \pm \\
\hline 10 & $++t$ & + & 24 & + & \pm \\
\hline 12 & $+t$ & \pm & 26 & + & 二 \\
\hline 13 & ++ & \pm & 27 & + & - \\
\hline 14 & & \pm & 28 & & - \\
\hline
\end{tabular}

*In this table +++ means strongly positive (no hemolysis); ++ , positive (distinct hemolysis without visible diminution in the layer of cells at bottom of tube); +, feebly positive (hemolysis with some diminution in the layer of cells at bottom of tube); \pm , plus-minus (marked hemolysis with only a faint layer of cells at bottom of tube); -, negative (complete hemolysis).

As already stated, the main purpose of the observations discussed in this paper was to find out how far positive Wassermann reactions in serums which showed a sufficient native antisheep amboceptor content could be affected by the addition of the usual dose of artificial amboceptor. In the series specially devoted to this purpose, our procedure has been to perform two separate reactions on such serums. One reaction was carried through without the addition of artificial amboceptor, i. e., with the Bauer modification, while the second reaction received the usual dose of artificial amboceptor. We have done a large number of reactions in this manner, of which seventy-seven serums showed a positive reaction to the Bauer modification.

Of these seventy-seven positive reactions forty-nine, or 63.6 per cent., remained unchanged by the addition of artificial amboceptor; while twenty-eight, or 36.4 per cent., were changed by the addition of artificial amboceptor.

Of the forty-nine reactions which were unchanged, forty-one were strongly positive $(+++)$; four were positive $(++)$ and four were feebly positive $(+)$. 
Of the twenty-eight reactions altered by the addition of artificial amboceptor, sixteen were classed as strongly positive. Of these sixteen reactions seven were changed to positive $(++)$; three were changed to feebly positive $(+)$; four were changed to plus-minus reactions $( \pm)$ and two became negative (-) (see table).

There were six reactions classed as positive. Of these two were changed to feebly positive reactions $(+)$; two were changed to plus-minus reactions $( \pm)$ and two became negative.

There were six reactions classed as feebly positive. Of these two became plus-minus reactions, and four became negative.

Further, there were eight reactions not counted in the above series, classed as plus-minus reactions, all of which became negative.

\section{CONCLUSIONS}

Of the twenty-eight positive reactions which were altered by the addition of artificial amboceptor, eight were changed to frankly negative reactions and eight became plus-minus reactions, which could not be considered positive. Thus it is interesting to note that out of the seventyseven serums observed, there were sixteen positive reactions (21.8 per cent.) which became either entirely negative or ambiguous and for practical purposes could only be considered negative.

It seems justifiable to conclude that while the presence of a native antisheep amboceptor in human serum is by no means constant, it is essential to take note of its presence or absence in performing the complement fixation test for syphilis by the Wassermann method, and that if this precaution be not taken, a certain and by no means very small percentage of positive reactions will be recorded as negative. By following this simple method of controlling the reaction, this error will be obviated to a large degree.

The Rose Building. 